\title{
Postępy w przeszczepieniach krwiotwórczych komórek macierzystych od dawców haploidentycznych
}

\author{
Advances in transplantation of hematopoietic \\ stem cells from haploidentical donors
}

\author{
Kazimierz Hałaburda \\ Klinika Transplantacji Komórek Krwiotwórczych, Instytut Hematologii i Transfuzjologii, Warszawa
}

\begin{abstract}
Streszczenie
Przeszczepienia krwiotwórczych komórek macierzystych od dawców haploidentycznych (haplo-HSCT) sa wykonywane coraz cześciej i obecnie stanowia ponad $10 \%$ przeszczepień allogenicznych raportowanych do EBMT. Upowszechnienie haplo-HSCT jest zwiazane z tatwościa identyfikacji $i$ dostęnościa dawców rodzinnych potowiczo zgodnych z biorcami, a przede wszystkim z wprowadzeniem wysokodawkowanego cyklofosfamidu w profilaktyce choroby przeszczep przeciwko gospodarzowi, stosowanego po przeszczepieniu. Mimo rosnacej liczby publikacji na temat haplo-HSCT ich wtaściwe miejsce $w$ terapii nadal nie jest precyzyjnie określone, chociaz $w$ retrospektywnych ocenach efekty tego rodzaju transplantacji oraz przeszczepień uznawanych za standardowe sa zblizone. Podobnie, kryteria kwalifikacji chorych oraz wyboru optymalnego dawcy wymagaja uściślenia.
\end{abstract}

Słowa kluczowe: przeszczepienie haploidentycznych krwiotwórczych komórek macierzystych, deplecja limfocytów T, cyklofosfamid

Hematologia 2015; 6, 1: 90-96

\begin{abstract}
Of late, haploidentical haematopoietic stem cells transplantations (haplo-HSCT) have been increasing and currently constitute more than $10 \%$ of allogeneic transplants reported to the EBMT. This upsurge in haplo-HSCT rates partly stem from the availability of donors but above all from introducing high dose cyclophosphamide, post-transplant, for graft versus host disease prevention; there being abundant literature on this subject. Nevertheless, the exact therapeutic role of haplo-HSCT remains to be defined although outcome assessments made retrospectively, show this not to signifcantly differ from standard allogeneic transplants. At present, there are no clear criteria to qualify patients for haplo-HSCT, nor for choosing the best of the available haploidentical family donors.

Key words: haploidentical hematopoietic stem cells transplantation, T-cell depletion, cyclophosphamide
\end{abstract}

Hematologia 2015; 6, 1: 90-96

Adres do korespondencji: Kazimierz Hałaburda, Klinika Transplantacji Komórek Krwiotwórczych, Instytut Hematologii i Transfuzjologii, ul. Indiry Gandhi 14, 02-776 Warszawa, tel. 223496 360, faks 223496 361,

e-mail: khalaburda@ihit.waw.pl 


\section{Wprowadzenie}

Przeszczepianie krwiotwórczych komórek macierzystych (HSCT, hematopoietic stem cells transplantation) jest dynamiczne rozwijającą się dziedziną hematologii. W ostatnim czasie obserwuje się istotne zmiany dotyczące technologii przeprowadzania transplantacji. Jednym $z$ przejawów zmian w ostatnich latach jest coraz częstsze wykorzystywanie komórek krwiotwórczych od rodzinnych dawców haploidentycznych, czyli połowiczo zgodnych $z$ biorcami w układzie ludzkich antygenów zgodności tkankowej (HLA, human leukocyte antigens). Prawdopodobieństwo zidentyfikowania zgodnego dawcy dla chorego posiadającego rodzeństwo wynosi około $25 \%$, zgodnego dawcy niespokrewnionego - 60-70\% (w populacji kaukaskiej), natomiast niemal każdy chory mający krewnych pierwszego stopnia ma potencjalnego, haploidentycznego dawcę komórek krwiotwórczych. Dowodem zainteresowania przeszczepieniami haploidentycznymi (haplo-HSCT, haploidentical hematopoietic stem cells transplantation) jest niemal 200 badań klinicznych zarejestrowanych na stronie clinicaltrials.gov. Ostatni opublikowany raport EBMT (European Group for Blood and Marrow Transplantation) wskazuje na znaczący wzrost wykonywanych haplo-HSCT. W 2013 roku do bazy danych EBMT zgłoszono 1571 takich transplantacji, co stanowi ponad $10 \%$ wszystkich przeszczepień allogenicznych (allo-HSCT, allogeneic HSCT) [1].

Pierwsze próby wykorzystania dawców haploidentycznych opisano ponad 30 lat temu u dzieci poddawanych transplantacjom $z$ powodu ciężkiego złożonego niedoboru odporności $-z$ dość dobrym efektem [2]. Natomiast transplantacje od rodzinnych dawców $z$ niepełną zgodnością $w$ układzie HLA w chorobach nowotworowych, gdzie stosowano identyczne postępowanie jak przy pełnej zgodności HLA, wiązały się $z$ wysoką częstością powikłań infekcyjnych, brakiem wszczepienia oraz chorobą przeszczep przeciwko gospodarzowi (GvHD, graft versus host disease). Ryzyko tych powikłań korelowało ze stopniem niezgodności HLA [3, 4]. Późniejsze lata przyniosły wiele prac opisujących haplo-HSCT selekcjonowanych komórek CD34 oraz przeszczepów pozbawianych limfocytów T (TCD, T-cell depleted) lub limfocytów T i B. Niewiele ośrodków w praktyce korzystało i nadal korzysta $z$ tej technologii ze względu na znaczne ryzyko powikłań oraz wysokie koszty związane $z$ procedurą. Dopiero zastosowanie przeszczepów niepoddawanych manipulacji in vitro (TCR, T-cell replete) pozwoliło na szersze upowszechnienie transplantacji od dawców haploidentycznych. Także w tym przypadku podstawą postępowania terapeutycznego jest zmniejszenie liczby limfocytów T i hamowanie ich funkcji. Odbywa się to jednak in vivo, co znaczne upraszcza procedurę transplantacyjną i umożliwia wykonywanie tego rodzaju przeszczepień na większą skalę. Dotychczas opublikowane wyniki haplo-HSCT wykonywanych tą metodą zachęcają do jej stosowania w wielu sytuacjach klinicznych. Aktualne doniesienia, których liczba w ostatnich latach gwałtownie się zwiększa, zawierają krótkoterminowe wyniki porównywalne z przeszczepieniami od rodzinnych i niespokrewnionych dawców w pełni zgodnych w układzie HLA [5]. Pozwalają także na ustalenie pewnych reguł postępowania. Liczba wykonywanych haplo-HSCT zwiększa się w ogromnym tempie i nie należy już uważać tego typu transplantacji za eksperyment medyczny.

\section{Kwalifikacja chorych}

Brakuje ścisłych wytycznych dotyczących zasad kwalifikacji pacjentów do haplo-HSCT. Istnieją dwa główne kryteria, które należy wziąć pod uwagę $\mathrm{u}$ chorych nieposiadających zgodnego w HLA dawcy rodzinnego. Pierwszym jest prawdopodobieństwo zidentyfikowania dostatecznie zgodnego w układzie HLA dawcy niespokrewnionego, drugim - pilność planowanej transplantacji. O ile chory nie ma dawcy zgodnego w HLA, a istnieje konieczność wykonania przeszczepienia, o tyle do wyboru pozostają dawca $z$ dopuszczalną niezgodnością w HLA, dawca haploidentyczny lub krew pępowinowa. W tym ostatnim przypadku często istnieją ograniczenia w postaci niedostatecznej zgodności, komórkowości lub barier finansowych. Przeprowadzenie transplantacji krwi pępowinowej nie pozwala także na infuzję limfocytów dawcy, jeśli byłyby do tego wskazania po przeszczepieniu. W Chinach, gdzie doświadczenie w wykonywaniu haplo-HSCT jest największe, powodem kwalifikacji pozostaje stosunkowo mała dostępność dawców niespokrewnionych, których w chińskim rejestrze (dopiero od 2012 roku należącym do światowego rejestru dawców) jest około 1,8 mln. W kraju tym haplo-HSCT stanowią ponad 30\% allo-HSCT [6]. Potencjalnymi kandydatami do haplo-HSCT moga być także chorzy, u których konieczne jest przeprowadzenie pilnej transplantacji lub procedury ratunkowej, na przykład $z$ powodu braku wszczepienia komórek krwi pępowinowej lub pobranych od dawcy niespokrewnionego. Również pacjenci leczeni $z$ powodu nawrotu choroby zasadniczej 
po wcześniejszej allo-HSCT mogą być brani pod uwagę jako kandydaci do haplo-HSCT [7]. Należy stwierdzić, że program postępowania w ośrodkach przeszczepowych powinien być tak opracowany, aby każdemu pacjentowi mającemu wskazania do allo-HSCT zapewnić możliwość wykonania takiej procedury - włączając przeszczepienie krwi pępowinowej lub haplo-HSCT [8].

\section{Wybór dawcy}

Jeżeli pacjent ma kilku potencjalnych dawców haploidentycznych, to należy dokonać wśród nich odpowiedniego wyboru, by zwiększyć prawdopodobieństwo powodzenia przeszczepienia. Trzeba podkreślić, że nie ma powszechnie przyjętych kryteriów selekcji dawców. Elementem, który bezwzględnie należy wziąć pod uwagę, jest obecność u biorcy przeciwciał przeciwko antygenom HLA dawcy (DSA, donor specific antibodies). Ich wykrycie informuje o znacznym ryzyku nieprzyjęcia przeszczepu lub co najmniej opóźnienia wszczepienia [9]. Uważa się, że najlepszą metodą badania DSA są testy fazy stałej wykonywane przy użyciu cytometru przepływowego (Luminex ${ }^{\mathrm{TM}}$ ), ponieważ pozwalają na wykrycie niskich mian przeciwciał. Mniejszą czułością charakteryzuje się wykonywanie próby krzyżowej z izolowanymi limfocytami T i B dawcy za pomocą cytometru przepływowego, najmniejszą — klasyczna, serologiczna próba krzyżowa $z$ izolowanymi limfocytami $\mathrm{T}$ i B. Należy jednak uznać, że ta ostatnia jest absolutnym minimum, które obowiązuje przed akceptacją dawcy. Zgodność biorcy i dawcy w zakresie głównych grup krwi może odgrywać rolę zwłaszcza przy przeszczepianiu szpiku (BM, bone marrow). Konieczność usunięcia z przeszczepu osocza lub krwinek czerwonych wiąże się $z$ utratą komórek macierzystych. Jest to szczególnie widoczne w TCD haplo-HSCT, w których odpowiednio duża liczba przeszczepianych komórek CD34 + ma krytyczne znaczenie. Jak udowodniono w przeszłości, przeszczepienie małej liczby komórek zmniejsza prawdopodobieństwo powodzenia procedury wykonywanej tą techniką. Czynnikiem, który także należy wziąć pod uwagę, jest wiek potencjalnego dawcy. W publikacjach na temat haplo-HSCT nie jest on elementem szczegółowo analizowanym. Historyczne dane dotyczące przeszczepiania szpiku wskazują, że wybór starszego dawcy może być czynnikiem niekorzystnie wpływającym na wyniki transplantacji [10]. Wydaje się więc, że także w haplo-HSCT wybranie młodszego dawcy jest właściwym rozwiązaniem. Następny element wymagający rozważenia to pokrewieństwo biorcy $i$ dawcy. Wczesne publikacje wskazywały na lepsze wyniki transplantacji - zarówno z pełną zgodnością, jak i częściowo niezgodnych w układzie HLA — jeśli komórki pobierano od matek, a nie ojców [11]. W późniejszym czasie obserwacje te potwierdzono, analizując wyniki TCD haplo-HSCT [12].

Ostatnio przedstawiono analizę wyników transplantacji u 1256 chorych poddanych przeszczepieniu $\mathrm{w}$ jednym $\mathrm{z}$ ośrodków chińskich [13]. Większość stanowili pacjenci połowiczo zgodni w HLA $z$ dawcami, natomiast pozostali wykazywali mniejszy zakres niezgodności. Chorym po kondycjonowaniu mieloablacyjnym przeszczepiano TCR komórki krwiotwórcze z BM i krwi obwodowej (PBSC, peripheral blood stem cells) pobierane po mobilizacji czynnikiem wzrostu. Jako profilaktykę GvHD stosowano leczenie bardziej intensywne niż po standardowych transplantacjach. Na podstawie tej analizy stwierdzono, że w przypadku przeszczepiania od rodziców lepsze wyniki obserwuje się, jeśli dawcami są ojcowie. Przedstawiono także algorytm wyboru dawców haploidentycznych w zależności od wieku, pokrewieństwa i dziedziczenia haplotypów HLA, biorąc pod uwagę ryzyko GvHD, nawrotu choroby zasadniczej oraz prawdopodobieństwo przeżycia całkowitego (OS, overall survival) i wolnego od choroby (DFS, disease-free survival). Za najlepszych dawców uznano dziecko dla rodzica oraz rodzeństwo niezgodne pod względem niedziedziczonego haplotypu matczynego (NIMA, non-inherited maternal antigens). Gorszymi dawcami w tej analizie okazało się starsze rodzeństwo, rodzeństwo $z$ niezgodnością niedziedziczonego haplotypu ojcowskiego (NIPA, non-inherited paternal antigens) oraz właśnie matki. Nie wiadomo jednak, czy zaproponowany algorytm zyskałby potwierdzenie we wszystkich rodzajach haplo-HSCT, w tym $z$ profilaktyką GvHD w postaci wysokodawkowanego cyklofosfamidu po transplantacji (ptCy, post-transplant cyclophosphamide). Kwestia wyboru optymalnego dawcy haploidentycznego pod względem pokrewieństwa oraz niezgodności NIMA i NIPA pozostaje zatem nadal otwarta.

Kolejnym elementem, który należy wziąć pod uwagę, jest zakres zgodności w zakresie HLA. W klasycznych allo-HSCT niezgodność HLA między dawcą i biorcą wpływa niekorzystnie na wyniki transplantacji. Wraz z rosnącą liczbą niezgodnych antygenów lub alleli zwiększa się ryzyko GvHD oraz śmiertelności związanej z leczeniem (TRM, treatment-related mortality) $[14,15]$. Odwrotne obserwacje poczyniono $\mathrm{w}$ odniesieniu do TCR haplo-HSCT z zastosowaniem ptCy. Wykazano, że 
obecność więcej niż 3 niezgodności HLA wpływ pozytywnie na odległe wyniki przeszczepienia, obniżając ryzyko nawrotu [16]. Sugeruje to, że $\mathrm{w}$ tym modelu kondycjonowania i profilaktyki GvHD preferowany jest dawca ściśle połowiczo zgodny w HLA $z$ biorcą. We wspomnianej wcześniej analizie $z$ ośrodka chińskiego $z$ kolei nie stwierdzono, by stopień niezgodności HLA miał istotne znaczenie dla ostatecznych wyników transplantacji [12]. Można zatem przypuszczać, że wyboru dawcy pod względem liczby niezgodnych $z$ biorcą antygenów HLA należy dokonywać w kontekście techniki przeszczepiania, jaka ma być zastosowana. Nie ma także jasności co do znaczenia niezgodności dawcy i biorcy pod względem immunoglobulinopodobnych receptorów komórek zabijających (KIR, killer immunoglobulin-like receptors) $\mathrm{i}$ ich ligandów. $\mathrm{W}$ ubiegłych latach podnoszono znaczenie alloreaktywności komórek naturalnej cytotoksyczności (NK, natural killers) warunkowanej przez tę niezgodność w TCD haplo-HSCT [17]. Z obserwacji wynikało, że występowanie niezgodności między KIR hamującym funkcję NK i jego ligandem obniża ryzyko nawrotu ostrej białaczki szpikowej (AML, acute myeloid leukemia) i zwiększa prawdopodobieństwo przeżycia chorych. Inne doniesienia tych obserwacji jednak nie potwierdziły; przeciwnie — w TCR haplo-HSCT odnotowano wyższe ryzyko GvHD i gorsze wyniki przeszczepiania w przypadku niezgodności KIR [18].

Obecnie brakuje jednoznacznych danych dotyczących wpływu nosicielstwa wirusa cytomegalii (CMV, cytomegalovirus) u biorcy i dawcy na wyniki haplo-HSCT. W tej kwestii należy się zatem kierować zasadami stosowanymi w innych rodzajach allo-HSCT. Dotychczas zaproponowano kilka różniących się od siebie algorytmów doboru dawcy haploidentycznego. Tym niemniej wspólną cechą, której istotność podkreśla się we wszystkich z nich, jest ujemny wynik DSA u biorcy.

\section{TCD haplo-HSCT}

Ponieważ GvHD stanowi główne zagrożenie dla chorych po przeszczepieniach od dawców niezgodnych w HLA, od ponad 30 lat stosuje się metody pozwalające na zmniejszenie in vitro liczby limfocytów $\mathrm{T}$ odpowiedzialnych za tę reakcję. $Z$ biegiem czasu obserwuje się trend polegający na zmianie $z$ selekcji pozytywnej komórek CD34+ na selekcję negatywną komórek CD3 i CD19. Wynika to $\mathrm{z}$ faktu, że pozytywna selekcja CD34+ pozbawia przeszczep pożądanych frakcji komórkowych, między innymi NK, limfocytów regulatorowych czy komórek dendrytycznych. Takie postępowanie zwiększa ryzyko powikłań infekcyjnych, nawrotu choroby zasadniczej oraz braku wszczepienia wskutek niemal zupełnego pozbawienia przeszczepu limfocytów CD3. Stosując selekcję negatywną CD3 i CD19, można zachować część limfocytów i podać choremu ich kontrolowaną liczbę, co wpływa korzystnie na wyniki transplantacji, obnizając jednocześnie ryzyko GvHD [19]. Najlepsze efekty obserwowano po przeszczepieniu dużej liczby komórek CD34+ izolowanych z cytaferez [20]. Zwłaszcza w ostatnich latach pojawiają się interesujące doniesienia o HSCT po manipulacji in vitro. Dvorak i wsp. [21] przeszczepili po kondycjonowaniu mieloablacyjnym 21 dzieciom średnio $22 \times 10^{6}$ komórek CD34+/kg mc. oraz stałą liczbę komórek CD3+ wynoszącą $3 \times 10^{4} / \mathrm{kg} \mathrm{mc}$. Dzięki takiemu postępowaniu wszczepienie uzyskano u 90\% dzieci; 2-letnie przeżycie wolne od zdarzeń niepożądanych wynosiło $100 \%$ u pacjentów poddanych przeszczepieniu $z$ powodu choroby nienowotworowej oraz $56 \%$, gdy powodem transplantacji był nowotwór hematologiczny [21]. Odpowiednio modyfikowany skład przeszczepu pozwala na osiaggnięcie dobrych wyników przeszczepiania także u dorosłych. Martelli i wsp. [22] opisali 43 chorych na AML ( $\mathrm{n}=33$ ) lub ostrą białaczkę limfoblastyczną (ALL, acute lymphoblastic leukemia) $(\mathrm{n}=10)$ wysokiego ryzyka, którzy nie mieli zgodnego dawcy rodzinnego ani niespokrewnionego. Pacjenci zostali poddani kondycjonowaniu mieloablacyjnemu, a następnie przeszczepiono im izolowane komórki CD34+, limfocyty regulatorowe oraz limfocyty $\mathrm{T}$ w ilościach odpowiednio $9,7 \times 10^{6} / \mathrm{kg} \mathrm{mc}$., $2,5 \times 10^{6} / \mathrm{kg} \mathrm{mc}$. oraz $1,1 \times 10^{6} / \mathrm{kg}$ mc.; po transplantacji chorzy nie otrzymywali leczenia immunosupresyjnego. Jedynie u 15\% zaobserwowano istotną klinicznie GvHD, a prawdopodobieństwo DFS po 46 miesiącach od transplantacji wyniosło $56 \%$. Nawroty choroby zasadniczej w tym czasie dotyczyły zaledwie $5 \%$ chorych [22]. Jednak zarówno u dzieci, jak i u dorosłych chorych opisywane $\mathrm{w}$ literaturze grupy poddawane transplantacji po deplecji limfocytów lub innej modyfikacji in vitro są niewielkie ze względu na skomplikowaną technikę i wysoki koszt procedury. Obecnie tylko kilka ośrodków na świecie kontynuuje programy transplantacji tego typu.

\section{Niepoddawane manipulacji in vitro przeszczepienia haplo-HSCT}

Jednym ze sposobów uzyskania dobrych wyników przeszczepień od dawców haploidentycznych 
jest metoda stosowana od kilkunastu lat w ośrodkach azjatyckich. Jest ona rozwijana szczególnie w szpitalu uniwersyteckim w Pekinie. Polega na poddaniu chorych intensywnemu kondycjonowaniu (cytarabina, busulfan, cyklofosfamid oraz simustyna), a następnie silniejszej niż standardowa immunosupresji (globulina antylimfocytowa w dużych dawkach w okresie kondycjonowania, cyklosporyna, metotreksat oraz mykofenolan mofetilu). U wszystkich pacjentów stosuje się krwiotwórcze komórki macierzyste pochodzące $z$ BM lub krwi obwodowej haploidentycznych dawców rodzinnych, po mobilizacji czynnikiem wzrostu granulocytów i niepoddawane żadnym manipulacjom [23]. W ocenie długoterminowej 756 chorych na różne typy białaczek (AML, ALL, przewlekła białaczka szpikowa [CML, chronic myelogenous leuekemia]) poddanych transplantacji tą metodą Wang i wsp. opisali 3-letnie prawdopodobieństwo DFS oraz OS wynoszące odpowiednio $63 \%$ i $67 \%$, natomiast 3-letnie ryzyko zgonu niezwiązanego $z$ nawrotem białaczki oszacowano na 18\% [24].

Yan i wsp. [25] przeanalizowali w tym samym ośrodku wyniki haplo-HSCT u chorych na ALL o wysokim ryzyku nawrotu (obecność choroby resztkowej po konsolidacji, zajęcie ośrodkowego układu nerwowego, immunofenotyp T). Według tych obserwacji haplo-HSCT pozwalała na uzyskanie równie wysokiego prawdopodobieństwa 5-letniego DFS i OS, jak u chorych z grupy niskiego ryzyka poddawanych tylko chemioterapii podtrzymującej. Prawdopodobieństwo takie po haplo-HSCT wyniosło odpowiednio 54,9\% i 70,5\% [25]. Podobny sposób postępowania przyjęli autorzy koreańscy, którzy w kondycjonowaniu zastosowali napromienienie całego ciała (TBI, total body irradiation) dawką 800 cGy, fludarabinę i dożylny busulfan. Chorym na AML przeszczepiano PBSC haploidentycznych dawców rodzinnych. Jako profilaktykę GvHD stosowano globulinę antylimfocytową, takrolimus oraz metotreksat. Po medianie obserwacji wynoszącej 26 miesięcy $\mathrm{u}$ chorych po przeszczepieniu w okresie pierwszej całkowitej remisji (CR) stwierdzono prawdopodobieństwo DFS oraz OS sięgające odpowiednio $75,1 \%$ i $82,5 \%$ [26].

\section{Zastosowanie wysokodawkowanego cyklofosfamidu po haplo-HSCT}

Pionierami odmiennego podejścia do haplo-HSCT są badacze z Baltimore oraz Seattle. W 1999 roku w tych dwóch ośrodkach rozpoczęto badania kliniczne polegające na stosowaniu ptCy.
Jak wykazano wcześniej, krwiotwórcze komórki macierzyste, ze względu na wysoką aktywność dehydrogenazy aldehydowej, są odporne na toksyczne działanie cyklofosfamidu i jego metabolitów [27]. Na modelu zwierzęcym udowodniono, że podanie tego leku w dużej dawce we właściwym czasie po HSCT zapobiega zarówno odrzuceniu przeszczepu, jak i GvHD [28]. Luznik i wsp. [28] poddali transplantacji 68 chorych $z$ zaawansowanymi nowotworami hematologicznymi. Pacjenci otrzymali kondycjonowanie niemieloablacyjne z zastosowaniem cyklofosfamidu, fludarabiny i TBI dawką 200 cGy; w 3. lub 3. i 4. dobie po haplo-HSCT chorym podawano cyklofosfamid w dawce $50 \mathrm{mg} / \mathrm{kg} \mathrm{mc}$./dobę. Od 5. doby po haplo-HSCT stosowano immunosupresję złożoną z takrolimusu oraz mykofenolanu mofetilu. W opisywanej grupie prawdopodobieństwo 2-letniego OS i przeżycia bez zdarzeń niepożądanych oszacowano odpowiednio na $36 \%$ i $26 \%$ [29].

Od czasu ukazania się tej pierwszej publikacji, a zwłaszcza w ciągu ostatnich 5 lat, liczba doniesień dotyczących zastosowania po haplo-HSCT ptCy wzrasta $z$ każdym miesiącem. Większość $z$ nich zawiera odległe wyniki nieodbiegające istotnie od uzyskiwanych po allo-HSCT od dawców niespokrewnionych, w tym zgodnych w HLA. Na podstawie analizy wielu publikacji Bashey i Solomon [30] pokusili się nawet o stwierdzenie, że haplo-HSCT z ptCy jest wyłaniającym się standardem postępowania u chorych niemających zgodnego dawcy rodzinnego. Dobre rezultaty są opisywane po przeszczepieniach nie tylko BM, ale także PBSC oraz po kondycjonowaniu mieloablacyjnym, także w wykorzystaniem TBI [31, 32]. Jest dostępnych wiele publikacji, w których zestawiono wyniki haplo-HSCT $z$ wynikami innych typów przeszczepień, ale są to wyłącznie retrospektywne analizy grup chorych różniących się istotnie między sobą, więc muszą być interpretowane $z$ dużą ostrożnością.

Di Stasi i wsp. [33] porównali wyniki transplantacji u chorych na AML i zespoły mielodysplastyczne poddawanych przeszczepieniom w $M D$ Anderson Cancer Center od dawców rodzinnych, niespokrewnionych oraz haploidentycznych z ptCy. Wszyscy chorzy otrzymywali kondycjonowanie niemieloablacyjne oparte na melfalanie i fludarabinie. Badacze nie wykazali istotnych statystycznie różnic w wynikach transplantacji w analizowanych grupach. W retrospektywnej ocenie grupy 227 chorych stwierdzili 3-letnie prawdopodobieństwo DFS wynoszące odpowiednio $57 \%$, $45 \%$ i $43 \%$ u pacjentów poddanych przeszczepieniu w okresie remisji [33]. Porównanie przeszczepień niespokrewnionej 
krwi pępowinowej (UCBT, unrelated cord blood transplantation) oraz haplo-HSCT $\mathrm{z}$ ptCy wskazuje, że lepszych wyników można oczekiwać w tym drugim przypadku. El-Cheikh i wsp. [34] opisali 150 dorosłych chorych na nowotwory hematologiczne, $z$ których 69 poddano haplo-HSCT, a 81 - UCBT. Prawdopodobieństwo zgonu niezwiązanego $z$ nawrotem po 12 miesiącach wyniosło $23 \%$ dla UCBT i $17 \%$ dla haplo-HSCT. Po UCBT obserwowano istotnie większą częstość ostrej i przewlekłej postaci GvHD. Prawdopodobieństwo DFS i OS po 24 miesiącach dla UCBT i haplo-HSCT wyniosło, odpowiednio, $45 \%$ i $69 \%$ $(\mathrm{p}=0,1)$ oraz $36 \%$ i $65 \%(\mathrm{p}=0,01)[34]$.

Przeszczepienia haploidentyczne $z$ wykorzystaniem ptCy mogą być $z$ powodzeniem stosowane nie tylko u chorych na nowotwory układów krwiotwórczego i chłonnego. Esteves i wsp. [35] opisali zastosowanie haplo-HSCT z ptCy u 16 chorych na nawrotową, oporną na leczenie anemię aplastyczną lub z brakiem wszczepienia po wcześniejszej allo-HSCT. Osiągnięte rezultaty wskazują na prawdopodobieństwo 12-miesięcznego OS na poziomie $67 \%$ [35].

\section{Podsumowanie}

W 2015 roku po raz pierwszy ukazały się wskazania EBMT do HSCT $z$ uwzględnieniem haplo-HSCT. Warto podkreślić, że haplo-HSCT znalazły się $\mathrm{w}$ jednej grupie zaleceń $z$ UCBT oraz allo-HSCT od dawców niespokrewnionych $z$ niepełną zgodnością w układzie HLA (poza niezgodnością w DQ B1). Grupę tę określono wspólnie jako transplantacje od dawców alternatywnych [36]. Na podstawie danych $z$ rejestru EBMT Piemontese i wsp. [37] wykazali, że haplo-HSCT wykonywane w okresie pierwszej CR u chorych na ostre białaczki wiąże się z 3-letnim prawdopodobieństwem DFS i OS wynoszącymi odpowiednio $44 \pm 6 \%$ i $55 \pm 6 \%$. Wyniki te nie odbiegają od danych rejestrowych w transplantacjach od zgodnych dawców niespokrewnionych. W analizie nie rozróżniano typu transplantacji od dawcy haploidentycznego pod względem stosowanego kondycjonowania czy profilaktyki GvHD. Uzyskane wyniki pozwoliły jednak na sformułowanie istotnego wniosku, $\dot{z} \mathrm{e}$ tego rodzaju przeszczepienia powinno się zawsze brać pod uwagę, jeśli nie można zidentyfikować dawcy w pełni zgodnego $z$ biorcą pod względem układdu HLA [37].

Jednocześnie Gorin i wsp. [38], również na podstawie danych $z$ rejestru EBMT, porównali wyniki haplo-HSCT i autologicznych HSCT (auto-
-HSCT) u chorych na ostre białaczki; ich wnioski na podstawie analizy dobranych par wskazały na lepsze wyniki auto-HSCT niż haplo-HSCT. Porównywalne rezultaty osiaggnięto jedynie w ośrodkach, których personel ma doświadczenie w wykonywaniu haplo-HSCT [38]. Zważywszy na obecnie dostępne procedury transplantacyjne, należy z rozwagą dokonywać odpowiedniego wyboru, mając na uwadze dobro pacjenta. W minionych 5 latach haplo-HSCT uzyskały status realnych opcji terapeutycznych. Jednak nadal powinno się je przeprowadzać w ramach badań klinicznych, aby w przyszłości można było określić ich właściwe miejsce $\mathrm{w}$ procesie leczenia chorych.

\section{Piśmiennictwo}

1. Passweg J.R., Baldomero H., Bader P. i wsp. Hematopoietic SCT in Europe 2013: recent trends in the use of alternative donors showing more haploidentical donors but fewer cord blood transplants. Bone Marrow Transplant. 2015; 50: 476-482.

2. Reisner Y., Kapoor N., Kirkpatrick D. i wsp. Transplantation for severe combined immunodeficiency with HLA-A,B,D,DR incompatible parental marrow cells fractionated by soybean agglutinin and sheep red blood cells. Blood 1983; 61: 341-348.

3. Beatty P.G., Clift R.A., Mickelson E.M. i wsp. Marrow transplantation from related donors other than HLA-identical siblings. N. Engl. J. Med. 1985; 313: 765-771.

4. Anasetti C., Amos D., Beatty P.G. i wsp. Effect of HLA compatibility on engraftment of bone marrow transplants in patients with leukemia or lymphoma. N. Engl. J. Med. 1989; 320: 197-204.

5. Bashey A., Zhang X., Sizemore C.A. i wsp. T-cell replete HLA-haploidentical hematopoietic transplantation for hematologic malignancies using post-transplantation cyclophosphamide results in outcomes equivalent to those of contemporaneous HLA-matched related and unrelated donor transplantation. J. Clin. Oncol. 2013; 31: 1310-1316.

6. LV M., Huang X.J. Allogeneic hematopoietic stem cell transplantation in China: where we are and where to go. J. Hematol. Oncol. 2012 Mar 18; 5: 10. doi: 10.1186/1756-8722-5-10.

7. Tischer J., Engel N., Fritsch S. i wsp. Second haematopoietic SCT using HLA-haploidentical donors in patients with relapse of acute leukemia after a first allogeneic transplantation. Bone Marrow Transplant. 2014; 49: 895-901.

8. Patriarca F., Luznik L., Medeot M. i wsp. Experts considerations on HLA-haploidentical stem cell transplantation. Eur. J. Haematol. 2014; 93: 187-197.

9. Yoshihara S., Maruya E., Taniguchi K. i wsp. Risk and prevention of graft failure in patients with preexisting HLA antibodies undergoing unmanipulated haploidentical SCT. Bone Marrow Transplant. 2012; 47: 508-515.

10. Kollman C., Howe C.W., Anasetti C. i wsp. Donor characteristics as risk factors in recipients after bone marrow transplantation from unrelated donors: the effect of donor age. Blood 2001; 98 : 2043-2051.

11. Tamaki S., Ichinohe T., Matsuo K. i wsp. Superior survival of blood and marrow stem cell recipients given maternal grafts over recipients given paternal grafts. Bone Marrow Transplant. 2001; 28: $375-380$. 
12. Stern M., Ruggeri L., Mancusi A. i wsp. Survival after T-cell depleted haploidentical stem cell transplantation is improved using the mother as donor. Blood 2008; 112: 2990-2995.

13. Wang Y., Ying-Jun C., Ping-Lan X. i wsp. Who is the best donor for a related HLA haplotype mismatched transplant? Blood 2014; 124: 843-850.

14. Petersdorf E.W., Gooley T., Malkki M., Horowitz M. Clinical significance of donor-recipient matching on survival after myeloablative hematopoietic cell transplantation from unrelated donors. Tissue Antigens 2007; 69 (supl. 1): 25-30.

15. Morishima Y., Sasazuki T., Inoko H. i wsp. The clinical significance of human leucocyte antygen (HLA) allele compatibility in patients receiving a marrow transplant from serologically HLA matched HLA-A, HLA-B, and HLA-DR matched unrelated donors. Blood 2002; 99: 4200-4206.

16. Kasamon Y.L., Luznik L., Leffell M.S. i wsp. Nonmyeloablative HLA-haploidentical bone marrow transplantation with high-dose post-transplant cyclophosphamide: effect of HLA disparity on outcome. Biol. Blood Marrow Transplant. 2010; 16: 533-542.

17. Ruggeri L., Mancusi A., Burchielli E. i wsp. NK cell alloreactivity and allogeneic stem cell transplantation. Science 2008; 40: 84-90.

18. Huang X.J., Zhao X.Y., Liu D.H. i wsp. Deleterious effect of KIR ligand incompatibility on clinical outcomes of haploidentical hematopoietic stem cell transplantation without In vitro T-cell depletion. Leukemia 2007; 21: 848-851.

19. Bethge W.A., Faul C., Bornhäuser M. i wsp. Haploidentical allogeneic hematopoietic stem cell transplantation in adults using CD3/ /CD19 depletion and reduced intensity conditioning: an update. Blood Cells Mol. Dis. 2008; 40: 13-19.

20. Aversa F., Tabilio A., Velardi A. i wsp. Treatment of high-risk acute leukemia with T-cell-depleted stem cells from related donors with one fully mismatched HLA haplotype. N. Engl. J. Med. 1998; 339: 1186-1193.

21. Dvorak C.C., Gilman A.L., Horn B. i wsp. Haploidentical related-donor hematopoietic cell transplantation in children using megadoses of CliniMACs-selected CD34(+) cells and a fixed CD3(+) dose. Bone Marrow Transplant. 2013; 48: 508-513.

22. Martelli M.F., Di Ianni M., Ruggeri L. i wsp. HLA-haploidentical transplantation with regulatory and conventional T-cell adoptive immunotherapy prevents acute leukemia relapse. Blood 2014; 124: 638-644.

23. Huang X.J., Liu D.H., Liu K.Y. Treatment of acute leukemia with unmanipulated HLA-mismatched/haploidentical blood and bone marrow transplantation. Biol. Blood Marrow Transplant. 2009; 15: 257-265.

24. Wang Y., Liu D.H., Liu K.Y. i wsp. Long-term follow-up of haploidentical hematopoietic stem cell transplantation without in vitro $\mathrm{T}$ cell depletion for the treatment of leukemia: nine years of experience at a single center. Cancer 2013; 119: 978-985.

25. Yan C.H., Jiang Q., Wang J. i wsp. Superior survival of unmanipulated haploidentical hematopoietic stem cell transplantation compared with chemotherapy alone used as post-remission therapy in adults with standard-risk acute lymphoblastic leukemia in first complete remission. Biol. Blood Marrow Transplant. 2014; 20 : 1314-1321.

26. Jahng S.A., Kim J.H., Jeon Y.W. i wsp. A well-tolerated regimen of 800 cGy TBI-fludarabine-busulfan-ATG for reliable engraftment after unmanipulated haploidentical peripheral blood stem cell transplantation in adult patients with acute myeloid leukemia. Biol. Blood Marrow Transplant. 2015; 21: 119-129.

27. Kastan M.B., Schlaffer E., Russo J.E. i wsp. Direct demonstration of elevated aldehyde dehydrogenase in human hematopoietic progenitur cells. Blood 1990; 75: 1947-1950.

28. Luznik L., Jalla S., Engstrom L.W., Iannone R., Fuchs E.J. Durable engraftment of major histocomaptibility-complex incompatible cells after nonmyeloablative conditioning with fludarabine, low-dose total body irradiation, and posttransplantation cyclophosphamide. Blood 2001; 98: 3456-3464.

29. Luznik L., O’Donell P.V., Symons H.J. i wsp. HLA-haploidentical bone marrow transplantation for hematologic malignancies using nonmyeloablative conditioning and high-dose, posttransplantation cyclophosphamide. Biol. Blood Marrow Transplant. 2008; 14: 641-650.

30. Bashey A., Solomon S. T-cell replete haploidentical donor transplantation using post-transplant CY: an emerging standard-of-care option for patients who lack an HLA-identical sibling donor. Bone Marrow Transplant. 2014; 49: 999-1008.

31. Solomon S.R., Sizemore C.A., Sanacore M. i wsp. Haploidentical transplantation using $\mathrm{T}$ cell replete peripheral blood stem cells and myeloablative conditioning in patients with high-risk hematologic malignancies who lack conventional donors is well tolerated and produces excellent relapse-free survival: results of a prospective phase II trial. Biol. Blood Marrow Transplant. 2012; 18: 1859-1866.

32. Castagna L., Cricchiolo R., Furst S. i wsp. Bone marrow compared with peripheral blood stem cells for haploidentical transplantation with nonmyeloablative conditioning regimen and post-transplantation cyclophosphamide. Biol. Blood Marrow Transplant. 2014; 20: 724-729.

33. Di Stasi A., Milton D.R., Poon L.M. i wsp. Similar transplantation outcomes for acute myeloid leukemia and myelodysplastic syndrome patients with haploidentical versus 10/10 human leukocyte antigen-matched unrelated and related donors. Biol. Blood Marrow Transplant. 2014; 20: 1975-1981.

34. El-Cheikh J., Crocchiolo R., Furst S. i wsp. Unrelated cord blood compared with haploidentical grafts in patients with hematological malignancies. Cancer 2015 Feb 3. doi: 10.1002/cncr.29271 [złożone do druku].

35. Esteves I., Bonfim C., Pasquini R. i wsp. Haploidentical BMT and post-transplant $\mathrm{Cy}$ for severe aplastic anemia: a multicenter retrospective study. Bone Marrow Transplant 2015 Mar 2. doi: 10.1038/bmt.2015.20 [złożone do druku].

36. Sureda A., Bader P., Cesaro S. i wsp. Indications for allo- and auto-SCT for haematological diseases, solid tumours and immune disorders: current practice in Europe, 2015. Bone Marrow Transplant. 2015 Mar 23. doi: 10.1038/bmt.2015.6 [złożone do druku].

37. Piemontese S, Ciceri F, Labopin M i wsp. A survey on unmanipulated haploidentical hematopoietic stem cell transplantation in adults with acute leukemia. Leukemia 2014 Dec 1. doi: 10.1038/ /leu.2014.336 [złożone do druku].

38. Gorin N.C., Labopin M., Piemontese S. i wsp. T-cell-replete haploidentical transplantation versus autologous stem cell transplantation in adult acute leukemia: a matched pair analysis. Haematologica 2015; 100: 558-564. 